\title{
Using HOTS-Based Chemistry National Exam Questions to Map the Analytical Abilities of Senior High School Students
}

\author{
Johnsen Harta $^{1 *}$, Novena Tesalonika Rasuh ${ }^{1}$, Angela Seriang ${ }^{1}$ \\ ${ }^{1}$ Chemistry Education Study Program, Faculty of Teacher Training and Education, Sanata Dharma University, Yogyakarta, Indonesia \\ *Corresponding author: johnsenharta@usd.ac.id
}

\begin{abstract}
High Order Thinking Skills (HOTS) are a significant part of the implementation of the 2013 Curriculum to develop student competencies in the 21st century. Not only in the context of learning are HOTS considered important. They contribute to the National Examination held in Indonesia, so careful preparation for this exam is needed. Chemistry has basic concepts that require students to search and find facts, understand concepts, apply them procedurally, and analyze deeply. This study aims to map the analysis ability of students in Yogyakarta in working on HOTS-based chemistry national exam questions. This research is a quantitative-qualitative descriptive study with XII year students at a senior high school in Yogyakarta. The instruments used in this study were HOTS essay questions, interview sheets, and questionnaire sheets, analyzed with the Rasch Model. The results show that the students' analysis ability was still relatively low, with person reliability values of 0.56 and 0.39 , and a Cronbach's alpha of 0.78 . The quality of the HOTS questions was very good, with item reliability 0.97 and 0.95 . Not many students in the two senior high schools have good analysis ability, so students must be better trained to optimize their potential in HOTS-based chemistry learning.
\end{abstract}

Keywords Analysis ability, National exam, Chemistry, Higher order thinking skills (HOTS)

\section{INTRODUCTION}

The national exam is one of the programs organized by the Indonesian Ministry of Education and Culture to measure the academic achievements of class XII students who will complete their level of education at senior high school / equivalent level. This program has caused controversy considering the unequal education in Indonesia. Constraints such as lack of adequate school facilities, not many teachers in several regions, and leakage of national exam answer keys that have occurred have caused the exam to be considered inadequate as a determinant of students' graduation. Schools are considered more equitable in deciding the graduation of students who have been undergoing learning and teaching activities. Since 2016, the moratorium of the national exam was rejected, so the 2017 national exam up to now has been packaged with a different appearance, for example, senior at high school level in natural sciences class, only tested four subjects namely mathematics, Indonesian, English, and one elective subject namely chemistry/biology/physics. In addition, the government has also begun implementing a Computer-Based National Exam throughout Indonesia.
The exam held contains questions that are based on HOTS because the HOTS concept is an important part of the 2013 Curriculum in Indonesia. Dinni (2018) explains that HOTS include the ability in problem-solving, creative thinking, critical thinking, the ability to reason, and the ability to make decisions. At least $10-15 \%$ of HOTS questions are presented in the computer-based national exam (Maulipaksi, 2019), for all subjects tested.

The majority of senior high schools in Yogyakarta have implemented the 2013 Curriculum. Demands on the competence of chemistry teachers to be able to train and develop HOTS for class XII senior high school students in the context of national exam preparation are important because chemistry subject has potential to develop many HOTS questions that can train and develop students' abilities to reach the HOTS level which includes analyzing (C4), evaluating (C5), and creating (C6) so that chemistry teachers are expected to be able to apply it at senior high school learning.

Received: 2 January 2020

Revised: 9 April 2020

Published: 15 July 2020 
The presence of HOTS brings new nuances and challenges in the chemistry national exam because students must be prepared to work on some HOTS-based chemistry questions. Saputra (2016: 91-92) emphasizes that the main purpose of the emergence of HOTS is to improve students' thinking abilities at a higher level, especially those related to the ability to think critically in receiving various information, think creatively in solving a problem using the knowledge they have and make decisions in complex situations.

The earliest HOTS level to do is analysis ability. Anderson \& Krathwohl (2001) explained that indicators to measure the ability to analyze (C4) could be investigated through students' efforts in fragmenting several components and connecting these components to obtain a complete understanding of concepts.

Based on the results of interviews with chemistry teachers in SMA A, the initial students' ability of Class XII Natural Science 4 is relatively good, but there are still grades that are below average. In chemistry learning, the teacher has already developed HOTS and tested the question in the Mid-Term and End Semester Assessment, although the number of items given is not much. Meanwhile, the chemistry teachers at SMA B said that the ability of students of class XII Natural Science 6 was in the good domain, and the chemistry teacher had given HOTS questions during the study, but the intensity was not very frequent. The teacher still wants students to finalize their readiness, especially later national exam questions so that they are more maximized in obtaining the final results. Both chemistry teachers agreed to carry out trials of the items used in this research. The chemistry teachers revealed that this research could help observe students 'ability to answer questions and investigate the students' analysis ability.

Politsinsky \& Demenkova (2015) explain that the process of practicing problem-solving skills is important, so the ability to analyze is considered as an effective part of the teaching process at school. Pratama \& Retnawati (2018) state that students are not only applying what they have learned, but ways to analyze also help to improve the various problems that can be encountered in life. Furthermore, it is emphasized that analytical skills in the 21 st century are very important to be needed in solving daily problems (Facione, 2015). Chemistry teachers are required to design learning that can direct students' abilities towards analysis, even though the facts are quite difficult because students need a process to start the process of thinking analysis. This ability can be trained, measured through test instruments developed in the topic of chemistry high school, and conducted a study of the analysis ability of high school students in dealing with HOTS-based chemistry questions.

\section{METHOD}

This research is a quantitative-qualitative descriptive study that focuses on investigating the analysis ability of senior high school class XII students while working on HOTS-based chemistry national exam questions. The population in this study were all students of class XII Natural Sciences at SMA A and B in Yogyakarta. Sampling was done by random sampling technique for each school so that two field trial samples were obtained, namely XII Natural Science 4 with 34 students from SMA A and XII Natural Science 6 with 30 students from SMA B.

The instrument used in this study was a validation sheet from two experts from lecturers and two chemistry teachers in SMA A and B, HOTS-based chemistry national exam questions, which consists of five items and a questionnaire sheet to analyze student responses. All figures and tables were attached in The Supplementary Information. Results of the validation from experts and chemistry teachers were analyzed using the Aikens' V formula to get the validity coefficient. The results of interviews with chemistry teachers were analyzed descriptively, while the results of the HOTS-based Chemistry national exam essay results and student response questionnaire sheets were analyzed using the Rasch model and descriptive.

Before the research was conducted, a visit to several senior high schools in Yogyakarta was chosen, and two classes from two senior high schools were selected as the research sample. This data is used as a preliminary reference to further investigate students' abilities and is processed together with trial results data in each school.

\section{RESULT AND DISCUSSION}

In mapping the analysis ability of class XII senior high school students in working on HOTS-based chemistry national exam questions, initial preparations were made in the form of validation of experts and chemistry teachers, trials in two classes, and analysis of test results to investigate students' ability to analyze (reaching C4 level in HOTS).

\subsection{Drafting and Developing Research Instruments for Measuring Analysis Ability}

From the end of July until August 2019 was carried out the preparation and development of research instruments such as validation instrument on a scale of four, an interview sheet with chemistry teachers, test instrument that consists of five HOTS items that had been selected from the Chemistry national exam questions from 2014 to 2018 and modified into chemistry essay questions related to periodic table properties, acid-base titration, salt hydrolysis, and solubility products, voltaic cells, and polymers. Thaneerananon, Triampo, \& Nokkaew (2016) emphasize that tests can help develop students' abilities in reflecting and developing critical thinking skills. After that, the student response questionnaire sheet was developed as 
a supporting instrument to determine student responses to HOTS items.

\subsection{Validating Research Instruments for Measuring Analysis Ability}

Validation for the research instrument was carried out by two experts from lecturers and two chemistry teachers in SMA A and B. Based on the results of experts validation, the average acquisition score for the validation of the interview sheet was 3.8 , and this indicated the quality of the instrument was classified as good.

Meanwhile, the results of the validation of experts and chemistry teachers on the five items of essay questions from the aspects of content, construction, and grammar get an average score of 3.9 and the average validity coefficient of 0.96 . Thus, all items have been declared valid and very good, and deserve to be tested on students of class XII in selected senior high schools.

The results of the validation of the student response questionnaire sheet to HOTS essay items tested were given an average score of 3.8 and the average validity coefficient of 0.94. This instrument was also declared valid and was appropriate to be given after students finished working on HOTS-based essay questions.

\subsection{Field Trial}

After validating and qualifying for quality, as many as five HOTS-based chemistry essay items were tested in class XII Natural Sciences 4 and XII Natural Sciences 6. Analysis of all components related to items and students' analysis ability on working HOTS-based chemistry national exam questions was conducted by referring to the Rasch model. Sumintono \& Widhiarso (2015: 84) state that the value of information conveyed through the Rasch model using the Winstep program is comprehensive and very good in the development of items in learning.

Irawati \& Mahmudah (2018) emphasize that the analysis ability is the basic ability of HOTS that must be developed. Laksono, Rohaeti, Suyanta, \& Irwanto (2017) state that the analysis ability as part of HOTS has three distinctive indicators, namely the ability to distinguish, organize, and connect. These three indicators are used to investigate the achievement of students' analysis ability and map them. This is in line with what was stated by Falvo (2008) that the learning process includes the activities of choosing (in this case, the context is to differentiate, organizing, and integrating) knowledge that occurs during the development stage of students' memory.

Mapping Students'Analysis Ability of Class XII Natural Science 4 at SMA A

Kusuma, Rosidin, Abdurrahman, \& Suyatna (2017) relate the relationship between analytical skills students must have and the competencies that must be achieved in 2013 Curriculum which are writing structure and classifying (factual), explaining and analyzing (conceptual), differentiating (procedural), and designing to find (metacognitive). All of these abilities are expected to be implemented in chemistry learning and equip students to pursue more in the fields of science, such as chemistry.

The distribution of students' abilities is shown in Figure S1 (Supplementary Information) and shows that the student's position is in the lower area, which indicates that the student's analysis ability still needs to be improved. Based on the information in Figure S4 (Supplementary Information), $\mathrm{AB}$ students have the highest score to solve these five HOTS questions, and student $\mathrm{J}$ is the student with the lowest score in this trial.

In an effort to reach the C4 level in HOTS, it is necessary to map students' analysis abilities (in terms of differentiating, organizing, and connecting) specifically in each item that can be explained as follows.

a. In item number 1 , the students' analysis ability is very weak. A total of 12 students do not have the good analytical ability, then 20 students are at a poor level, and only two students are good enough to distinguish information about electron affinity and electronegativity, then rearrange and relate it. Weak understanding of student concepts regarding the electronegativity of elements and their properties is still found. Reading experiences make it easier for students to master concepts (Probosari, Widyastuti, Sajidan, Suranoto, \& Prayitno, 2018). Futhermore, Prastiwi \& Laksono (2018) state that the assessment developed by the teacher could have an opportunity to stimulate students' analytical thinking skills, and the ability of chemistry literacy also influenced the ability to analyze. As in this study, the HOTS test instrument is able to reveal the level of students' analytical skills, can students have to enrich themselves by reading, understanding, and analyzing in-depth.

b. In item number 2 , there were still six students who were unable to answer because they did not have competence in analyzing. In addition, the level of unfavorable is still occupied by 18 students, the level is quite good only achieved by three students, the good level is successfully done by six students, and only one student is the best in analyzing this item. The majority of students are still unable to rearrange pieces of information and relate them through calculations involving acid-base titration.

c. In item number 3, there are ten students who are not competent in terms of distinguishing, organizing, and connecting two concepts in a single unit. A total of 22 students are at a poor level, and only two students are the most competent at analyzing. Vong \& Kaewurai (2017) reveal that identifying and investigating are just a few of the keys to successful learning. These two parts are certainly part of the ability to analyze students. The majority of students are suspected of being unable to differentiate and relate the concepts of salt hydrolysis and solubility products.

d. In item number 4 regarding voltaic cells, only six students were poor in terms of rearranging information and linking it, four students were at a good level, four students 
were at a good level, and 20 students dominated at a very good level in analyzing. The majority of students can already work on this item well. Analytical thinking involves a series of mental processes needed to find the right solution to overcome various problems so that this ability can be trained and developed during the learning process (Anwar \& Mumthas, 2014).

e. In item number 5, there are 31 students who are still incompetent in differentiating, rearranging, and connecting each concept in the polymerization reaction, then two students are at a poor level, and only one student is good enough to analyze this problem. Zhang (2003) and Yang \& Lin (2004) explained that identify is like combining informative instruction, so students have a variety of approaches and develop HOTS abilities, which in this case are specialized in analytical skills.

Based on the above information, results of the mapping, as seen in the Supplementary Information (Figure S1), and also the ability of students (Figure S4), it does seem that the students' analysis ability is still low in HOTS-based Chemistry national exam questions. This is also supported by the value of the person reliability of 0.56 (Figure S3), indicating the analysis ability of students who are still weak.

Anggraini, Budiyono, \& Pratiwi (2018) state that each student has a different way of finding and solving a problem. With this in mind, the inculcation of problemsolving skills in analyzing is needed and must be built.

In the chemistry test as many as five essay items for Class XII Natural Science 4, amounting to 34 students had an item reliability value of 0.97 (Figure S3), which showed the quality of the items developed was very special. According to the results of the measurement and analysis of item measures in Figure S5, it was noted that item 5 had the highest difficulty level (a measure of 1.47), and question number 4 was the easiest problem (measure -1.86) that students could work on.

\section{Mapping Students' Analysis Ability of Class XII Natural Science 6 at SMA B}

The distribution of students' abilities is shown in Figure S2 (Supplementary Information) and shows that the student's position is in the lower area, which indicates that the student's analysis ability still needs to be trained and developed again. Based on the information in Figure S7 (Supplementary Information), AD students have the highest scores for completing these five HOTS questions, and $\mathrm{X}$ students are the students with the lowest scores in this trial.

In an effort to reach the C4 level in HOTS, it is necessary to map students' analysis abilities (in terms of differentiating, organizing, and connecting) specifically in each item that can be explained as follows.

a. In item number 1 , the students' analysis ability is very weak. A total of 19 students did not have good analysis abilities in terms of differentiating, organizing, and connecting. Meanwhile, as many as 11 students are at a bad level. The students' understanding of concepts is weak and needs to be sharpened in order to be able to distinguish electron affinity and electronegativity of elements, rearrange new concepts, and link the relationships between the two personality traits of these elements. In addition, literacy-based questions are also important to be understood and analyzed further. Mahatoo (2012) states that the ability to read carefully and thoroughly and understand the context becomes an important part of analyzing. Futhermore, Prawita, Prayitno, \& Sugiyarto (2019) explains that generative learning and reading interest can improve analytical thinking skills.

b. In item number 2, there were still five students who were unable to analyze the questions because they did not have competency in analyzing. In addition, the level of unfavorable is still occupied by three students, the level of good enough is dominated by 13 students in arranging the information to be done, the good level is only successful in 3 students, and six students are the best in analyzing this item. The majority of students are quite capable of rearranging, but it is still not stable in connecting information and calculations involving acid-base titration. Singaravelu (2017) revealed that students' analytical skills are still weak, so it is suggested that teachers can emphasize more problem-based exercises and develop students' problem-solving.

c. In item number 3 , there are 26 students who are not competent in terms of distinguishing, organizing, and connecting several concepts in the solution of chemistry. As many as two students are at a poor level, and only two students are the most competent at analyzing. Politsinsky, Demenkova, \& Medvedeva (2015) state that the ability to analyze is a logical basis that relates the picture, nature, and relationships of each section, which can be separately identified into a new entity. The majority of students are suspected of being unable to differentiate and relate the concepts of salt hydrolysis and solubility products. Seventika, Sukestiyarno, \& Mariani (2018) emphasize that the weak ability of students to analyze can be caused by one of them because students solve problems without proper analysis procedures, weak mathematical logic, and cannot apply the concepts needed for analytical skills.

d. In item number 4 regarding voltaic cells, there are 19 students dominating at the level of incompetence in rearranging information and linking it, two students who are not good at analyzing, two students are at a good enough level, three students are at a good level, and only four students who are very good at analyzing. Students still need a lot of learning to understand, rearrange, and connect them appropriately.

e. In item number 5 , there are 28 students who are not competent in distinguishing, rearranging, and linking some information relating to the polymerization reaction. There are only two students who are at a poor level in analyzing 
this item. Students still need to learn a lot about basic concepts and slowly practice analytical skills in learning. Organizing information is a process needed to analyze so that a larger collection of information will be obtained and will produce a good understanding (Areesophonpichet, 2013). Changwong, Sukkamart, \& Sisan (2018) state that problem-solving requires the ability to think critically, and it is stressed here that the ability to analyze and create is at the heart of critical thinking. Thus, analytical skills must be mastered and sharpened by students.

Based on the results of the mapping (Figure S2) and students' ability (Figure S7), it does seem that the students' analysis ability is still low in HOTS-based Chemistry national exam questions. This is also supported by the value of the person reliability of 0.39 (Figure S6), indicating the ability of students who are still weak. Yulina, Permanasari, Hernani, \& Setiawan (2018) explain that analytical thinking skills expose students to logical thinking and relate to the current situation in terms of categorizing, explaining, comparing, contrasting, and re-examining everything that is done.

In the chemistry test as many as five essay items for class XII Natural Science 6, amounting to 30 students had an item reliability value of 0.95 (Figure S6), which showed the quality of the items developed was very special. According to the results of the measurement and analysis of item measures in Figure S8 (Supplementary Information), it was noted that item 5 had the highest difficulty level (a measure of 1.59), and question number 2 was the easiest problem (measure -1.31) that students could work on.

The analysis ability of XII students in both schools is still relatively weak, even though the quality of all chemistry items tested to each class has been classified as very good. This needs to be supported by the role of chemistry teachers who must strengthen the basic abilities and develop HOTS abilities of students during learning at school in order to improve students' abilities in answering chemistry national exam questions. Hadi, Retnawati, Munadi, Apino, \& Wulandari (2018) state that difficulties in analyzing are still experienced by most students. Therefore, efforts should be made so that HOTS can be developed slowly in learning. Furthermore, Harta (2019: 72) explained that the development of HOTS in learning is in accordance with the orientation of the 2013 Curriculum in the 21 st century so that students are more capable of mastering science and its applications. The learning process that is getting better, meaningful, and quality will determine the ability of students to develop competent analysis ability. Through the information entered, according to Winarti (2015), states that the activity of analyzing starts from structuring information into smaller parts, recognizing a thing, and formulating questions.

After students finish working on the HOTS questions, students are asked to fill in the students' response questionnaire sheet to the item being tested. The majority of students find it quite difficult to analyze problems; students can understand concepts but are hesitant in connecting information. The relationship between data and theory made by students has not been able to provide a related picture that is being studied (Saptono, Rustaman, Saefudin, \& Widodo, 2016). However, students are challenged to try other items, later on, to enrich their insights and improve their analytical ability. The final results of the analysis of this questionnaire sheet gave Cronbach's alpha value of 0.78 , which indicates that the consistency of this instrument is quite good.

Cesarandari, Aswandi, \& Oikurema (2019) state that the ability to analyze will affect other skills such as the ability to present orally can even change a student's bad habits, making students more responsible. In this way, a holistic assessment can be carried out. Irwanto, Rohaeti, Widjajanti, \& Suyanta (2017) revealed that the analytical thinking skills used in theoretical chemistry learning are very important to be developed and further integrated into chemical experiments, which also require analytical skills. Analytical skills are not only important in terms of developing students' abilities in learning, but also contribute to life problems (Schumacher \& Ifenthaler, 2018).

\section{CONCLUSION}

Based on the research and discussion that has been done, it can be concluded that the analysis abilities in terms of distinguishing, organizing, and connecting possessed by students of class XII Natural Science 4 and 6 are still relatively weak. This is evident from the students' person reliability values of 0.56 and 0.39 which indicate the weakness of the analysis ability, even though the quality of HOTS items tested was valid and feasible to use, as well as the results of the questionnaire analysis with Cronbach's alpha value of 0.78 which included both in terms of consistency. The results of the mapping analysis of students' analysis ability in each item also showed the students' weakness in distinguishing some basic chemistry concepts, the difficulty of rearranging information, and being unable to link the information available and the initial knowledge students had. This analysis ability needs to be familiarized and trained during chemistry learning at senior high school, so students are more mature and can improve their analysis competency.

\section{ACKNOWLEDGMENT}

The authors would like to say many thanks to the Institute for Research and Community Service, Sanata Dharma University, Yogyakarta, Chemistry Education Study Program of Sanata Dharma University, Yogyakarta, and also Sogang University, South Korea. This research was supported by the Leading University Project for International Cooperation through the National Research 
Foundation of Korea (NRF) funded by the Ministry of Education (MOE) number= 2015H1A7A2A02037456).

\section{REFERENCES}

Anderson, O. W. \& Krathwohl, D. R. (2001). A taxonomy for learning, teaching, and assessing (a revision of Bloom's taxonomy of educational objectives). Addision Wesley Longman, Inc.

Anggraini, N. P., Budiyono \& Pratiwi, H. (2018). Analysis of higher order thinking skills students at junior high school in Surakarta. Journal of Physics: Conference Series, 1211(012077), 1-9.

Anwar, B. \& Mumthas, N. S. (2014). Taking triarchic teaching to classrooms: Giving everybody a fair chance. International Journal of Advanced Research, 2(5), 455-458.

Areesophonpichet, S. (2013). A development of analytical thinking skills of graduate students by using concept mapping. The Asian Conference on Education, 1, 15.

Cesarandari, S., Aswandi \& Oikurema. (2019). Applying the Higher Order Thinking Skills (HOTS) to spoken analytical exposition in oral presentation assessment. IOSR Journal of Research \& Method in Education, 9(2), 1-5.

Changwong, K., Sukkamart, A., \& Sisan, B. (2018). Critical thinking skill development: Analysis of a new learning management model for Thai high schools. Journal of International Studies, 11(2), 37-48.

Dinni, H. N. (2018). HOTS (High Order Thinking Skills) dan kaitannya dengan kemampuan literasi matematika. PRISMA, Prosiding Seminar Nasional Matematika, 1, 170-176.

Facione, P. A. (2011). Critical thinking: What it is and why it counts. Insight Assessment, 2007(1), 1-23.

Falvo, D. (2008). Animations and simulations for teaching and learning molecular chemistry. International Journal of Technology in Teaching and Learning, 4(1), 68-77.

Hadi, S., Retnawati, H., Munadi, S., Apino, E., \&Wulandari, N. F. (2018). The difficulties of high school students in solving higher-order thinking skills problems. Problems of Education In The 21st Century, 76(4), 520-532.

Harta, J. (2019). Kajian kurikulum kimia SMA dan SMK. Deepublish.

Irawati, T. N. \& Mahmudah, M. (2018). Pengembangan instrumen kemampuan berpikir analisis siswa smp dalam menyelesaikan soal pemecahan masalah matematika. Kadikma, 9(2), 1-11.

Irwanto, Rohaeti, E., Widjajanti, E., \& Suyanta. (2017). Students' science process skill and analytical thinking ability in chemistry learning. AIP Conference Proceedings, 1868(030001), 1-4. https://doi.org/10.1063/1.4995100

Kusuma, M. D., Rosidin, U., Abdurrahman, \& Suyatna, A. (2017). The development of Higher Order Thinking Skill (HOTS) instrument assessment in physics study. Journal of Research \& Method in Education, 7(1), 26-32.

Laksono, E. W., Rohaeti, E., Suyanta, \& Irwanto. (2017). Instrumen penilaian kemampuan berpikir analitis dan keterampilan proses sains kimia. Jurnal Kependidikan. 1(1), 100-110.

Mahatoo, J. (2012). Scientific literacy and nature of science as it impacts on boys' achievement in South Trinidad (Doctoral dissertation).

Maulipaksi, D. (2019, March 27). Tingkeat kesulitan soal UN 2019 tidak berubah, ini komposisi soalnya. Kementrian Pendidikan dan Kebudayaan. https://www.kemdikbud.go.id/main/blog/2019/03/tingkatkesulitan-soal-un-2019-tidak-berubah-ini-komposisi-soalnya

Politsinsky, E. \& Demenkova, L. (2015). The organization of the training of technical college students using practice-oriented tasks. Asian Social Science, 11(1), 187-192.

Politsinsky, E., Demenkova, L., \& Medvedeva, O. (2015). Ways of students training aimed at analytical skills development while solving learning tasks. Procedia - Social and Behavioral Sciences, 206 (1), $383-387$.

Pratama, G. S. \& Retnawati, H. (2018). Urgency of Higher Order Thinking Skills (HOTS) content analysis in mathematics textbook.
Journal of Physics: Conference Series, 1097 (1), 1-8. 10.1088/17426596/1097/1/012147

Prastiwi, M. N. B. \& Laksono, E. W. (2018). The ability of analytical thinking and chemistry literacy in high school students learning. Journal of Physics: Conference Series, 1097(1), 1-8. 10.1088/17426596/1097/1/012061

Prawita, W., Prayitno, B. A., \& Sugiyarto (2019). Effectiveness of a generative learning based biology module to improve the analytical thinking skills of the students with high and low reading motivation. International Journal of Instruction, 12(1), 1459-1476.

Probosari, R. M., Widyastuti, F., Sajidan, S., Suranoto, S., \& Prayitno, B. A. (2018). Reading for tracing evidence: Developing scientific knowledge through science text. Journal of Physics: Conference Series. 1022(1), 1-6.

Saptono, S., Rustaman, N. Y., Saefudin, \& Widodo, A. (2016). Memfasilitasi HOTS dalam perkuliahan biologi sel melalui model integrasi atribut asesmen formatif. Unnes Science Education Journal, 5(3), 1403-1412.

Saputra, H. (2016). Pengembangan mutu pendidikan menuju era global: Penguatan mutu pembelajaran dengan penerapan HOTS (High Order Thinking Skills). SMILE's Publishing.

Schumacher, C., \& Ifenthaler, D. (2018). Features students really expect from learning analytics. Computers in Human Behavior, 78, 397-407.

Seventika, S. Y., Sukestiyarno, Y. L., \& Mariani, S. (2018). Critical thinking analysis based on Facione (2015) - Angelo (1995) logical mathematics material of vocational high school (VHS). Journal of Physics: Conf. Series, 983(1), 1-6. 10.1088/1742-6596/983/1/012067

Singaravelu, S. (2017). Problem solving ability of higher secondary chemistry students. IOSR Journal of Research \& Method in Education (IOSR-JRME), 7(4), 19-22.

Sumintono, B. \& Widhiarso, W. (2015). Aplikasi pemodelan rasch pada assesment pendidikan. Trim Komunikata.

Thaneerananon, T., Triampo, W., \& Nokkaew, A. (2016). Development of a test to evaluate students' analytical thinking based on fact versus opinion differentiation. International Journal of Instruction, 9(2), 123-138.

Vong, S. A., \& Kaewurai, W. (2017). Instructional model development to enhance critical thinking and critical thinking teaching ability of trainee students at regional teaching training center in Takeo province, Cambodia. Kasetsart Journal of Social Sciences, 38(1), 88-95.

Winarti. (2015). Profil kemampuan berpikir analisis dan evaluasi mahasiswa dalam mengerjakan soal konsep kalor. Jurnal Inovasi dan Pembelajaran Fisika, 2(1), 19-24.

Yang, S. C., \& Lin, W. C. (2004). The relationship among creative, critical thinking and thinking styles in Taiwan high school students. Journal of Instructional Psychology, 3(1), 33-45.

Yulina, I. K., Permanasari, A., Hernani, H., \& Setiawan, W. (2018). Analytical thinking skill profile and perception of pre service chemistry teachers in analytical chemistry learning. Journal of Physics: Conference Series, 1157(4), 1-7. 10.1088/1742-6596/1157/4/042046

Zhang, L. F. (2003). Contributions of thinking styles to critical thinking. Journal of Psychology, 137(6), 517-544. 